This Journal is available in Telkom University online Journals

Jurnal Manajemen Indonesia

\title{
Can The IDX Be Hedged? : Comparison of Black-Scholes Option Model And GARCH Option Model Using Long Strangle Strategy
}

Riko Hendrawan ${ }^{1}$, Gede Teguh Laksana ${ }^{2}$ and Wiwin Aminah ${ }^{3}$

1,2,3 Telkom University, Faculty of Economics and Business, Bandung, Indonesia.

\begin{abstract}
The purpose of this research was to compare the accuracy of the Black-Scholes option model and the GARCH option model on index options using IDX Composite (IHSG) data from 2009-2018 with the long strangle strategy. The Black-Scholes volatility constructed by using historical volatility, while GARCH volatility constructed by using the ARIMA model and the best lag. The accuracy of options analyzed using the average percentage mean square error (AMSE) to find the best model. The results of this study showed that for the one month option, the GARCH model is more accurate for a call option with 0.26\%, while the Black-Scholes model is more accurate for a put option with $0.18 \%$. For the two month option, the GARCH model is more accurate for a call option with $0.92 \%$, while the Black-Scholes model is more accurate for a put option with 0.26\%. For the three month option, the Black-Scholes model is more accurate for a call option and put option with $2.00 \%$ and $0.31 \%$, respectively. The results of this study further sharpen the research conducted by Bhat and Arekar (2016) and Hendrawan(2010).
\end{abstract}

Keywords - Black-Scholes Options Model; GARCH Option Model; Long Strangle; ,Index Option.,

\begin{abstract}
Abstrak
Tujuan dari penelitian ini adalah untuk membandingkan keakuratan model opsi Black-Scholes dan Model Opsi GARCH pada indek opsi menggunakan data IHSG dari tahun 2009-2018 dengan mengggunakan Strategi Long Strangel. Volatilitas historis digunakan pada model Black-Scholes, sedangkan model volatilitas GARCH dibangun berdasarkan lag terbaik dari model ARIMA. Untuk menguji keakuratan dari dua model tersebut digunakan average percentage mean square error (AMSE) untuk menemukan model yang terbaik. Hasil penelitian ini menunjukkan bahwa untuk opsi satu bulan, model GARCH lebih akurat untuk opsi call dengan $0,26 \%$, sedangkan model Black-Scholes lebih akurat untuk opsi put dengan $0,18 \%$. Untuk opsi dua bulan, model GARCH lebih akurat untuk opsi call dengan 0,92\%, sedangkan model Black-Scholes lebih akurat untuk opsi put dengan 0,26\%. Untuk opsi tiga bulan, model Black-Scholes lebih akurat untuk opsi call dan put option, masingmasing dengan $2,00 \%$ dan $0,31 \%$. Hasil penelitian ini semakin mempertajam penelitian yang dilakukan oleh Bhat dan Arekar (2016) dan Hendrawan(2010)
\end{abstract}

Kata kunci - Black-Scholes Options Model; GARCH Option Model; Long Strangle; Index Option.

\section{INTRODUCTION}

In investing, especially in the capital market, investors need to consider the returns and risks of these shares. The level of risk to be received is as large as the level of benefits to be obtained. Through the movement of the stock index, the value can also be known as the value of returns from the sale and purchase of shares received by investors within a specified period. Hendrawan and Nugroho (2018) stated that operating efficiency not only can increase the value of company but also the return of the stock. During 2014-2018 the yields from the IDX composite experienced very diverse fluctuations. Based on data from 2014-2018, the yields for 2014, as presented in Figure 1 below show that the highest yields were at the level of 3.18\%, which occurred on March 14, 2014, and the lowest results at the level of $-3.21 \%$ that occurred on April 10, 2014. In 2015, the highest yield was $4.45 \%$, which occurred on August 27, 2015, and the lowest yield was $-4.05 \%$ on August 24, 2019. Then in 
2016, the highest yield was at 2.81\%, which occurred on February 5, 2016, and the results the lowest at the level of $-4.09 \%$, which occurred on November 11, 2016. Then in 2017, the highest yields were found at the level of $2.56 \%$, which occurred on May 19, 2017, and the lowest results at the level of $-1.82 \%$, which occurred on November 30, 2017. While in 2018, the yield obtained the highest results at the level of 2.63\%, which occurred on May 24, 2018, and the lowest level at the level of $-3.83 \%$, which occurred on September 5, 2018.

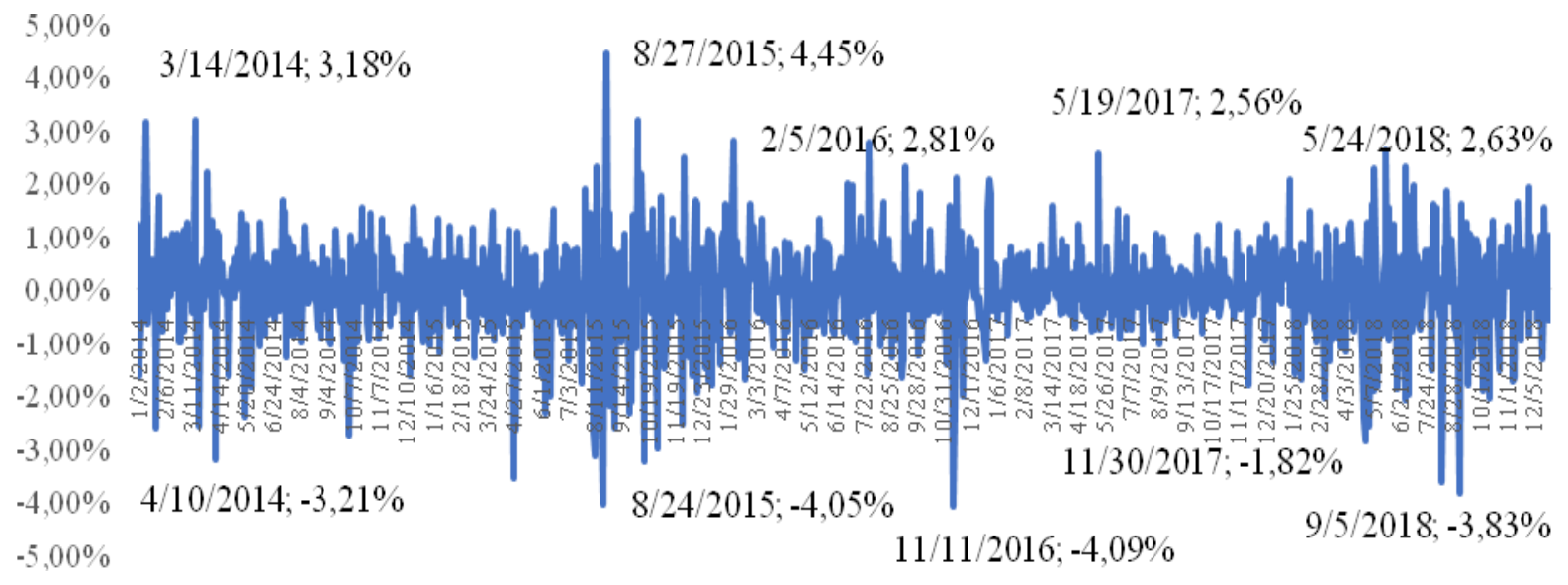

Figure 1. Daily Returns IHSG 2014-2018 (references: data processed)

Furthermore, if we look at the past ten years as shown in table 1 below, it is known that the highest yield was $7.01 \%$ on May 26, 2010, and the smallest yield was $-9.30 \%$ on September 22, 2011. The table also shows that the largest range was $13.95 \%$ in 2011 . Then the largest average percentage of return was $4.10 \%$, the lowest average percentage of return is $-4.36 \%$, and the average range value was $8.45 \%$.

Table 1. Daily Returns IHSG in last ten years

\begin{tabular}{lcccc}
\hline \multicolumn{1}{c}{ The Smallest Daily Returns } & \multicolumn{2}{c}{ The Biggest Daily Returns } & \multirow{2}{c}{ Range } \\
\cline { 1 - 3 } Dates & Percentage & \multicolumn{1}{c}{ Date } & Percentage & \\
\hline 05 September 2017 & $-3.83 \%$ & 24 May 2018 & $2.63 \%$ & $6.46 \%$ \\
\hline 30 November 2017 & $-1.82 \%$ & 19 May 2017 & $2.56 \%$ & $4.38 \%$ \\
\hline 11 November 2016 & $-4.09 \%$ & 05 February 2016 & $2.81 \%$ & $6.90 \%$ \\
\hline 24 August 2015 & $-4.05 \%$ & 27 August 2015 & $4.45 \%$ & $8.50 \%$ \\
\hline 10 April 2014 & $-3.21 \%$ & 14 March 2014 & $3.18 \%$ & $6.39 \%$ \\
\hline 19 Jugust 2013 & $-5.75 \%$ & 19 September 2013 & $4.54 \%$ & $10.29 \%$ \\
\hline 22 September 2011 & $-3.90 \%$ & 06 June 2012 & $3.27 \%$ & $7.17 \%$ \\
\hline 05 May 2010 & $-9.30 \%$ & 27 September 2011 & $4.65 \%$ & $13.95 \%$ \\
\hline 18 June 2009 & $-3.89 \%$ & 26 May 2010 & $7.01 \%$ & $10.90 \%$ \\
\hline Average & $-3.72 \%$ & 05 January 2009 & $5.87 \%$ & $9.59 \%$ \\
\hline ferences: data processed) & $-4.36 \%$ & Average & $4.10 \%$ & $8.45 \%$ \\
\hline
\end{tabular}

The data in Figure 1 and Table 1 shows that there is uncertainty (risk) faced by investors through the volatility of the IDC composite daily returns. The volatility of this movement can provide benefits to investors and usually investor used mutual fund to the risk (Hendrawan and Sumantri, 2013). The investors must be able 
to reduce risk to avoid losses in investing, one of them by using derivative instruments as a hedging tool. In the investment world, there are various instruments as hedging tools, one of which is options. Since the introduction of the Black-Scholes method, the use of options in modern financial theory and its application in trade has grown (Hendrawan, 2018). Black-Scholes (1973), in his research, introduced a model for determining the price of an option contract in the future. Then the GARCH (Generalized Autoregressive Conditional Heteroscedasticity) model, which is the development of the ARCH (Autoregressive Conditional Heteroscedasticity) model which used to determine the price of an option contract in the future. The difference between the two is in the calculation of volatility that will be examined in this study. Research on options theory has been carried out by many researchers using a variety of methods.

In the long strangle strategy, investors bet there will be a significant price movement, but it is uncertain whether the price increases or decreases. The advantage of this strategy will always be obtained in the movement of stock prices that are far away, limited risk, and unlimited profit potential if prices move far. The disadvantages of this strategy require significant movement to gain profits (Hull, 2009). Thus the use of the long strangle strategy to limit losses at a minimum and expect profits from stock prices to move significantly down or significantly up at any time on the stock market.

Some previous studies used the Black-Scholes model and the GARCH model with the strangle strategy. Liu (2009) conducted a study of the estimated volatility of the Hong Kong stock market using the GARCH model. Data from this study uses secondary data from Yahoo Finance regarding the closing price of the HIS (Hang Seng Index) for the period of January 2, 2002, to July 31, 2007. The first approach for modeling volatility in the stock market is the historical average price approach and the GARCH model. The historical average price is only the average yield variance over the existing data period. The GARCH model used is GARCH, ExponentialGARCH, Threshold-GARCH, Component-GARCH, and Asymmetric-CGARCH. The results of this study indicate that the GARCH model with a non-normal distribution has a good volatility forecast performance compared to the historical average price approach. The E-GARCH model with non-normal conditional volatility has a more accurate out-of-sample forecast performance.

Hendrawan (2010) compared the Black-Scholes option model and the GARCH option model for Astra, BCA, Indofood, and Telkom stock options on the Indonesia Stock Exchange. This study aims to find the best lag of the GARCH model, which formed from the best ARIMA. The selection of the best GARCH model seen from the smallest AIC and SIC. Then the GARCH model is best estimated for its variance value as a basis for calculating the option premium value. In conducting the estimation, secondary data for intraday stock trading used in January-March 2005. Data for testing the model uses secondary data for intraday trading of stock options contracts in April-June 2005 and as a reference for redemption, data for closing stock prices in MayAugust 2005. The analysis method uses the average percentage square error (AMSE) to test a model in which the smaller the value, the better the model is. The research shows that the GARCH model is more accurate than Black-Scholes for the period of options of one month, two months, and three months respectively, with an average correction relative to the average percentage root square error of each of $28.10 \%, 23.30 \%$, and $20 \%$.

Based on the results of an analysis of previous research that has been described, research that uses index options, especially the IDX composite on the Indonesia Stock Exchange, has never been done before. Therefore, this study aims to compare the accuracy of the Black-Scholes option model and the GARCH option model on the IDX composite (IHSG) using the long strangle strategy in 2009-2018 for one month, two months and three months.

\section{LITERATURE REVIEW}

\section{A. Black-Scholes Option Model}

An option is a contract that gives the owner the right to sell or buy an asset at an agreed price, time, and amount in the future. The price of a stock option affected by six main factors namely the spot price of the stock $(\mathrm{S})$, the redemption price/execution $(\mathrm{X})$, the maturity date $(\mathrm{T})$, volatility $(\sigma)$, the risk-free interest rate $(\mathrm{Rf})$, and the dividend (Hull, 2009). In 1973 a Black \& Scholes model was developed by Fischer Black and Myron Scholes and Robert Merton to set option prices. The Black \& Scholes model continues to grow until it becomes imperative in the development of the model and has a significant influence on the world of options trading and hedging. Black-Scholes is a pricing model used to determine the fair price or value for call options and put options (Hull, 2009). Based on Hendrawan (2017), the Black-Scholes equation for call options is as follows: 
$C=S N(d 1)-e^{-R_{f} T} X N(d 2)$

While the formula for the put option is as follows:

$P=X e^{-R_{f} T} N(-d 2)-S N(-d 1)$

Where:

$\mathrm{d} 1=\left(\ln \frac{[s / X]+\left[R_{f}-\frac{\sigma^{x}}{2}\right]}{\sigma \sqrt{T}} T\right)$

$\mathrm{d} 2=d 1-\sigma \sqrt{T}$

Where :

$\mathrm{S} \quad=$ Spot price

$\mathrm{X} \quad=$ Exercise price

$\mathrm{T}=$ Time maturity

$R_{f} \quad=$ Risk-free interest rate

$\sigma \quad=$ variance in stock price/volatility

$\mathrm{N}\{\}=$. cumulative normal standard distribution

\section{B. GARCH Option Model}

The GARCH model was developed by Bollerslev (1986) to improve the ARCH model. The Autoregressive (AR) condition has several requirements, such as the data must be stationary, where the data are in the average or fixed line of the normal observation variant. So that, the data is not far from the average line in the graph. The GARCH model can explain as follows:

$\sigma_{t}^{2}=\alpha_{0}+\alpha_{1} e_{t-1}^{2}+\cdots+\alpha_{p} e_{t-p}^{2}+\lambda_{1} \sigma_{t-1}^{2}+\cdots+\lambda_{q} \sigma_{t-q}^{2}$

Where:

$p \quad=$ shows ARCH element

$q \quad=$ shows GARCH element

$e_{t-p} \quad=$ variable from last the last $\mathrm{x}$ period

During the period, the influence can be limited in the GARCH model.

\section{Strangle Option Strategy}

Strangle is an options strategy that consists of call options and put options that have the same maturity but different redemption prices. The redemption price on the put option is lower than the call option. In the strangle strategy, investors bet there will be significant price movements, but it is uncertain whether the price increases or decreases. The advantage of this strategy will always be found in the movement of stock prices that are far away, limited risk, unlimited profit potential if prices move far, and are cheaper than a straddle. The disadvantages of this strategy require significant movement to gain profits (Hull, 2009).

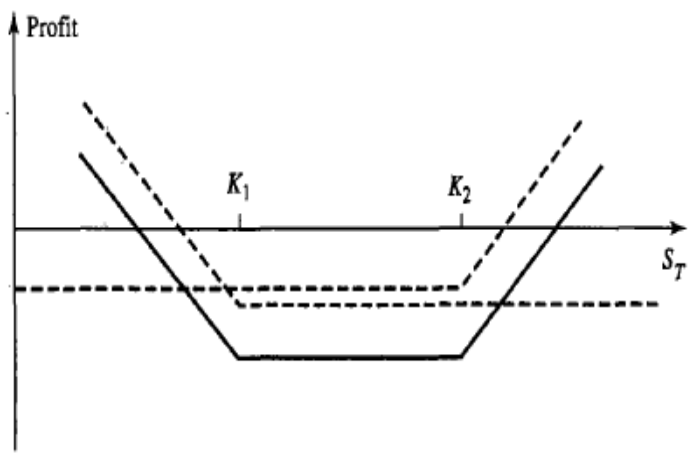

Figure 2. Long Strangle Strategy (source: Hull, 2009) 


\section{Previous Research}

Onwukwe (2011) in his research modeling the volatility of stock returns from four companies namely UB A, Unilever, Guinness and Cars listed on the Nigerian Stock Market. Data from this study uses secondary data from the daily closing price of the Nigeria Stock Exchange from January 2, 2002, to December 31, 2006. The research uses different heteroscedastic models, namely GARCH (1.1), EGARCH (1.1), and GJR-GARCH. These models estimated by assuming the Gaussian distribution using the Brendt-Hall-Hall-Hausman (BHHH) algorithm program. The results from this study, it was found that the GJR-GARCH model $(1,1)$ provides a better match to the data and is superior to other models both in evaluating estimates within the sample and outside the sample.

Huang et al. (2011), in his study, tried to compare the out-of-sample performance of the Black-Scholes model, Stochastic Volatility (SV), and GARCH on the options market on Taiwan Stock Exchange. The data used refers to the Taiwan Economic Journal, with daily closing prices on the Taiwan options market from December 30, 2003, to December 31, 2008. The performance measurements of each model use RPE (Relative Pricing Error) and ARPE (Absolute Relative Pricing Error), where the model with errors in the mean, median, and elementary near zero the best. The variables used are maturity, money, and binary variables. The results of this study indicate that the performance of the GARCH model is the best, with SV slightly dominating the Black-Scholes model. The price-fixing error decreases consistently over time, and the out-of-sample performance in the put option is more accurate than the call option. Thus the GARCH model performs the best modeling in the options market in Taiwan.

Gabriel (2012) conducted a study to evaluate the performance of the GARCH model in terms of in-sample and out-of-sample forecasting accuracy on the Bucharest Stock Exchange in Romania. This research data uses secondary data on International data stream with daily yields on the BET index from 3 September 2001 to 29 February 2012. The research uses various models of GARCH, TGARCH, PGARCH, IGARCH, and EGARCH to evaluate the volatility that occurs. In conducting a thorough evaluation of the normal distribution function, Student-t, and General Error Distribution (GED) are used to calculate errors. From the research conducted, it concluded that the daily yields could be modeled with a GARCH type model. Wherefrom several types of GARCH, the TGARCH and PGARCH $(1,2,1)$ models are the best in out-of-sample capability. In the end, this study found that the TGARCH model was the most appropriate in modelling the BET index volatility.

Abdalla (2012), in his research, modeling the volatility of exchange rates in nineteen Arab countries using the GARCH model. The data used in this study refers to the data of the brother from www.oanda.com/currency/realtime with the daily yields of the exchange rates of nineteen Arab countries against the US dollar from January 1, 2000, to November 19, 2011. The method used is the GARCH model to investigate the characteristics of volatility and $\mathrm{EGARCH}$ to capture the effects of leverage that occurs. From the research conducted, it concluded that GARCH could well model the volatility of currency exchange rates. This model is shown in the high volatility against ten of the nineteen currencies, while seven other currencies are quite persistent. The EGARCH results $(1,1)$ find the leverage effect on all currencies except the Jordanian Dinar (JOD), where the volatility in the next period is more negative than positive.

Bi et al. (2014) conducted a study to estimate the volatility used in determining future stock prices or stock options using the Black-Scholes-Merton model and the GARCH model. Stock options analysis conducted on ten companies from ten different sectors. The data used are the closing price of shares of NSE foam from May 1, 2012, to April 30, 2013, with a period of 30 days, 60 days, and 90 days. The volatility values obtained from each model used to calculate call options and put options. The conclusion from this study found that significantly the option is costly, but the price will decrease over a long period. Then it was also found that the value of the put option is more expensive than the call option, especially for a longer period time.

Sheraz and Preda (2014), in their research, try to use the volatility obtained from the GARCH method into the Black-Scholes model. This research was conducted based on a scientific test of the Black-Scholes formula with the volatility of GARCH. It is known that the volatility in the Black-Scholes model is constant, while the volatility in GARCH is not constant. The results of this study obtained the pattern of volatility that is close to the volatility of stocks or other assets that is not constant every time.

Bhat and Arekar (2016) conducted a study to compare the performance of US dollar currency option pricing against Indian Rupees traded using the Black-Scholes and NGARCH models. The data used are daily call option closing prices in US dollars against Indian Rupees traded on the NSE stock exchange from May 1, 2013, to October 31, 2013. This period was chosen because of its extreme volatility during the period. The researcher 
concludes that the Black-Scholes model outperforms the NGARCH model in pricing performance, and the GARCH model is free from the bias of moneyness and maturity shown by the orthogonality test.

Krishnan and Raju (2018) conducted a study to analyze the performance of straddle and strangle strategies on the Nifty 50 index option on the Indian Stock Exchange. This study applies a long straddle and long strangles strategy by taking European call and put options with a contract of one month, two months, and three months. From this research, the strangle strategy yields higher yields in Sharpe and Treynor ratios, but the Alpha Jensen ratio produces negative yields on one month contracts. Furthermore, on a two month and three month contract, the strangle strategy yields better returns than a straddle.

Kaur et al. (2018) conducted a study to assess the profitability of the returns from using a neutral options strategy in USD-INR. Kaur uses option strategies in the form of the long straddle, short straddle, long strangle, and short strangle executed in three different ways, namely out-of-the-money (OTM), in-the-money (ITM) and at-the-money (ATM)). The results of this study indicate that there is a wide variation with the large volatility in yields, but there is no significant difference between each option strategy used.

\section{RESEARCH METHODS}

This study uses quantitative methods with comparative and descriptive approaches, namely research conducted with the aim that researchers know the comparison of the accuracy of the Black-Scholes option model and the GARCH option model. This study uses secondary data taken in the form of the daily closing price of the IDX. The observational data for the period January 1, 2009 - December 30, 2018, for testing data for the period February 1, 2009 - March 31, 2019. If the due date falls on a holiday, then the implementation date uses the work price the day after the holiday. Then the BI Rate data/7 Days Rate Repo, so there is no data difference during the observation period, the Black-Scholes model calculated using historical volatility every year. As for the GARCH model, ARMA modelling performed to find the best lag from ARMA. After getting the best ARMA model, then GARCH lag modelling is performed by calculating the smallest AIC. GARCH volatility calculation is done after getting the best GARCH model. After obtaining the value of volatility using the historical volatility and volatility of $\mathrm{GARCH}$, proceed with determining the initial stock price, redemption price, risk-free interest rate, and option period. Furthermore, the calculation of the call and put option values based on the analytic model of the Black-Scholes model. The analytical method used is the average percentage square root error (average percentage mean squared error) to test a model where the smaller the value, the better the model. In general, the AMSE formula is as follows (Hendrawan, 2010):

$\mathrm{AMSE}=\frac{1}{N} \sum_{t=1}^{N}\left(\frac{A P t-S P t}{A P t}\right)^{2}$

Where :

Apt $=$ Actual premium value

$\mathrm{SPt}=$ Premium value of the result of the model calculation

$\mathrm{N}=$ Number of experiments conducted

\section{RESULT AND DiSCUSSION}

\section{A. Results for the Option Maturity of OneMonth}

Table 2. Comparative Results of the Accuracy of the Black-Scholes Option Model and GARCH Option Model for time maturity One month

\begin{tabular}{|c|c|c|c|c|}
\hline \multirow{4}{*}{$\begin{array}{c}\text { One } \\
\text { Month }\end{array}$} & \multirow[b]{2}{*}{ Option } & \multicolumn{2}{|c|}{ AMSE } & \multirow[b]{2}{*}{ Results } \\
\hline & & $\begin{array}{l}\text { Black- } \\
\text { Scholes }\end{array}$ & GARCH & \\
\hline & CALL & $0.32 \%$ & $0.26 \%$ & The GARCH (1.1) model better than the Black-Scholes model \\
\hline & PUT & $0.18 \%$ & $0.19 \%$ & The Black-Scholes model better than the GARCH (1.1) model \\
\hline
\end{tabular}

source: data processed 
Table 2 shows that for one month, the GARCH model has an average percentage of error square root of $0.26 \%$ for calls and $0.19 \%$ for put while the Black-Scholes model has an average percentage of square root errors of $0.32 \%$ for calls and $0.18 \%$ for put. Similarly, the calculation of the average percentage error square root for each Black-Scholes and GARCH models uses a long strangle strategy for one month.

\section{B. Results for the Option Maturity of Two Month}

Table 3. Comparative Results of the Accuracy of the Black-Scholes Option Model and GARCH Option Model for time maturity Two month

\begin{tabular}{|c|c|c|c|c|}
\hline \multirow{4}{*}{$\begin{array}{c}\text { Two } \\
\text { Month }\end{array}$} & \multirow[b]{2}{*}{ Option } & \multicolumn{2}{|c|}{ AMSE } & \multirow[b]{2}{*}{ Results } \\
\hline & & $\begin{array}{l}\text { Black- } \\
\text { Scholes }\end{array}$ & GARCH & \\
\hline & CALL & $0.98 \%$ & $0.92 \%$ & The GARCH (1.1) model better than the Black-Scholes model \\
\hline & PUT & $0.26 \%$ & $0.74 \%$ & The Black-Scholes model better than the GARCH (1.1) model \\
\hline
\end{tabular}

source: data processed

Table 3 shows that for two months the GARCH model has an average percentage of error square root of $0.92 \%$ for calls and $0.74 \%$ for put while the Black-Scholes model has an average percentage of square root errors of $0.98 \%$ for calls and $0.26 \%$ for put. Thus the AMSE calculation for each Black-Scholes and GARCH model uses a long strangle strategy for two months.

\section{Results for the Option Maturity of Three Month}

Table 4. Comparative Results of the Accuracy of the Black-Scholes Option Model and GARCH Option Model for time maturity Three month

\begin{tabular}{|c|c|c|c|c|}
\hline \multirow{3}{*}{$\begin{array}{l}\text { Three } \\
\text { Month }\end{array}$} & \multirow[b]{2}{*}{ Option } & \multicolumn{2}{|c|}{ AMSE } & \multirow[b]{2}{*}{ Results } \\
\hline & & $\begin{array}{l}\text { Black- } \\
\text { Scholes }\end{array}$ & GARCH & \\
\hline & CALL & $2.00 \%$ & $2.03 \%$ & The Black-Scholes model better than the GARCH (1.1) model \\
\hline & PUT & $0.31 \%$ & $1.00 \%$ & The Black-Scholes model better than the GARCH (1.1) model \\
\hline
\end{tabular}

source: data processed

Table 4 shows that for three months, the GARCH model has an average percentage error square root of $2.03 \%$ for calls and $1.00 \%$ for put while the Black-Scholes model has an error rate of $2.00 \%$ for calls and $0.31 \%$ for put. Thus the AMSE calculation for each Black-Scholes model and the GARCH model uses a long strangle strategy for three months.

\section{Discussion}

Based on the results of research on the IDX composite (IHSG) using the Black-Scholes and GARCH models with a long strangle strategy for one month shows that the GARCH model call is more accurate than the BlackScholes model in the valuation of option prices. Whereas the Black-Scoles model put is more accurate than the GARCH model, as seen from the smaller average percentage of the square root of the error. Then for the past two months, the GARCH model call option is more accurate than the Black-Scholes model in valuing the IHSG option price. Whereas the Black-Scholes put model is more accurate than the GARCH model, as seen from the smaller average percentage square root error.

Furthermore, for three months, the call and put options for the Black-Scholes model are more accurate than the GARCH model in the valuation of option prices, seen from the smaller average percentage of the square root of the error. However, the longer the agreed time, the two option models have a higher error rate. The results of the study show that the error rate for three months is higher than a period of two months and one month option.

The results of this study further sharpen the research conducted by Bhat and Arekar (2016), which proves that the Black-Scholes option model that uses historical volatility in modelling its volatility during the option period can be applied in Indonesia especially stock indexes. This is shown from the results of research in which 
the Black-Scholes option model tends to be more precise in predicting the premium value of stock options contracts especially during the 2009-2018 period so that the historical model of volatility can be considered for use on the Indonesia Stock Exchange.

\section{CONCLUSSION}

The purpose of this research was to compare the accuracy of the Black-Scholes option model and the GARCH option model on index options using data from 2009-2018 at IDX Composite with the long strangle strategy. Where the accuracy of options is analyzed using the lowest average percentage root error (AMSE). The results of this study indicate that for the one month option period the GARCH model is more accurate than the Black-Scholes model for calls with an average percentage of square root error of $0.26 \%$, while the BlackScholes model is more accurate than the GARCH model for put with an average percentage the square root error of $0.18 \%$. For the two month option period of the GARCH model is more accurate than the Black-Scholes model for calls with an average percentage of the square root error of $0.92 \%$, while the Black-Scholes model is more accurate than the GARCH model for the put with an average percentage average square root error of $0.26 \%$. For the three month option the Black-Scholes model is more accurate than the GARCH model for call and put with each average percentage square root error of $2.00 \%$ and $0.31 \%$.

\section{REFERENCES}

Abdalla, S. Z. S. (2012). Modelling exchange rate volatility using GARCH models: Empirical evidence

Bhat, A., \& Arekar, K. (2016). Empirical performance of Black-Scholes and GARCH option pricing models during turbulent times: the Indian evidence. International Journal of Economics and Finance, 8(3), 123136.

Bi, Z., Yousuf, A., \& Dash, M. (2014). A Study on Options Pricing Using GARCH and Black-Scholes-Merton Model. Asian Journal of Finance \& Accounting, 6(1), 423-439.

Black, F., \& Scholes, M. (1973). The pricing of options and corporate liabilities. Journal of political economy, 81(3), 637-654.

Bollerslev, T. (1986). Generalized autoregressive conditional heteroskedasticity. Journal of econometrics, 31(3), 307-327.

Gabriel, A. S. (2012). Evaluating the forecasting performance of GARCH models. Evidence from Romania. Procedia-Social and Behavioral Sciences, 62, 1006-1010.

Hull, J. (2009). Option, Futures And Other Derivatives (7th edition). New Jersey: Pearson Education, Inc.

Hendrawan, R. (2010). Perbandingan Model Opsi Blackscholes Dan Model Opsi Garch Di Bursa Efek Indonesia. Jurnal Keuangan dan Perbankan, 14(1), 13-23.

Hendrawan, R. (2017). Forward, forward option, and no hedging which one is the best for managing currency risk. Jurnal Keuangan dan Perbankan, 21(3), 356-365.

Hendrawan, R. (2018). Assessing shock volatility using long straddle option strategy: Evidence at IDX Composite. Jurnal Keuangan dan Perbankan, 22(1), 1-13.

Hendrawan, R., \& Nugroho, K. W. (2018). Telecommunication sector reform in Southeast Asia: A new rationality. Global J. Bus. Soc. Sci. Review, 6(4), 147-154.

Hendrawan, R., \& Sumantri, M. B. A. (2013). Efficiency of Indonesia's Mutual Funds During 2007-2011 by Using Data Envelopment Analysis (Dea). Jurnal Keuangan dan Perbankan, 17(1), 106459.

Huang, H. H., Wang, C. P., \& Chen, S. H. (2011). Pricing Taiwan option market with GARCH and stochastic volatility. Applied financial economics, 21(10), 747-754.

Kaur, A., Kapur, S., \& Gupta, M. (2018). Payoffs from Neutral Option Strategies: A Study of USD-INR Market. Journal of Economics, Management and Trade, 1-11.

Krishnan, D., \& Raju, G. (2018). Performance Analysis of Volatile Strategy under Indian Options Market. Indian Journal of Commerce and Management Studies, 9(1), 87-94.

Liu, W., \& Morley, B. (2009). Volatility forecasting in the hang seng index using the GARCH approach. AsiaPacific Financial Markets, 16(1), 51-63.

Onwukwe, C. E., Bassey, B. E. E., \& Isaac, I. O. (2011). On modeling the volatility of Nigerian stock returns using GARCH models. Journal of mathematics research, 3(4), 31.

Sheraz, M., \& Preda, V. (2014). Implied volatility in black-scholes model with GARCH volatility. Procedia Economics and Finance, 8, 658-663. 